\section{Measurement and modeling of race and health in Brazil: continuing the discussion}

\author{
Medição e modelagem de raça e saúde no Brasil: \\ continuando a discussão
}

Medición y modelización de raza y salud en

\section{Brasil: continuando la discusión}

COMUNICAÇÃO BREVE

BRIEF COMMUNICATION
Margaret T. Hicken 1

doi: $10.1590 / 0102-311 \times 00084216$

\begin{abstract}
Recent reviews have discussed the conceptualization of race in health studies in Brazil. This review further documents and discusses specific measurement and modeling issues with regard to race and how this can impact result interpretation. Three scientific databases were used to search the literature on race and three health outcomes. The search yielded 38 empirical studies on birth outcomes, self-rated health, and weight. Results suggest that, while there are racial patterns in the overall literature, conceptual and methodological challenges can be addressed to clarify the ways in which racial group membership is linked to health.
\end{abstract}

Ethnic Groups; Social Determinants of Health; Social Sciences

\author{
Correspondence \\ M. T. Hicken \\ Institute for Social Research, University of Michigan. \\ 426 Thompson Street, Ann Arbor / Michigan - 48106, U.S.A \\ mhicken@umich.edu \\ 1 Institute for Social Research, University of Michigan, Ann \\ Arbor, U.S.A.
}




\section{Introduction}

There has been growing interest in documenting variation in health outcomes by ethnoracial or skin color group (from here called "race") in Brazil, as race is thought to capture important social exposures that result in health inequalities 1 . Recently, scholars have assessed the approaches to the measurement of race in the health literature 2,3,4,5,6. Furthermore, they have discussed the conceptualization of race, calling for more theory-driven and explicit modeling of race 2,3,4. This report builds on and expands those reviews by examining how: (a) race is measured; and (b) modeled; and (c) how covariates are modeled with race in the health literature. These three factors will be evaluated and the implications for result interpretation will be discussed.

\section{Methods}

The literature was searched using three databases: PubMed, Latin American and Caribbean Literature in Health Sciences (LILACS), and Scientific Electronic Library Online (SciELO) with the following search terms in either the article title or abstract: (a) Brazil*; AND (b) race or color or ethnicity; AND (c) health. This search yielded 395 articles from PubMed, 205 from LILACS, and 737 from SciELO, with publication dates ranging from 1970 to 2015. After removing duplicate articles, there were 290 articles, published from 1997 to 2015. Articles were further omitted if they: (a) were not empirical (i.e., not reviews or commentaries); (b) did not examine human health; (c) did not model a race variable; (d) focused on outcomes other than infant birth outcomes, adult self-rated health, and adult weightrelated health. The final search yielded 12 articles on infant birth outcomes, 11 on self-rated health, and 15 on weight outcomes.

It was necessary to narrow the health focus to adequately examine patterns in the health outcomes. Each outcome captures different aspects of long- and short-term social, economic, and political processes and also represents the range of health data (e.g, vital records, national and local surveys). Infant birth outcomes are a sensitive indicator of an area's social condition ${ }^{7}$. Self-rated health is a general appraisal of one's physical and mental health and has been shown to be related to numerous morbidities and mortality 8 . Obesity is a growing global health concern, with evidence suggesting that social inequalities underly recent trends 9 . Together, these health outcomes cover survey and official vital data; samples and censuses; mental and physical health; subjective and objective measures; and long-standing and more recent health issues.

Articles were reviewed to determine whether race was a focus of the analysis and to assess the approaches to the measurement and modeling of race and the modeling of covariates. Then, race coefficients were examined across studies to provide a brief overview of racial patterns in health. Finally, issues linking the measurement and modeling of race are discussed in relation to the interpretation to these patterns in health.

\section{Results}

While 38 articles were examined, several articles included statistical models for different health outcomes (e.g., neonatal mortality, preterm birth), different demographic groups (e.g., gender), and different race measures for a total of 83 models. (A list of the articles included is available upon request).

Regarding the measurement approach, results are consistent with those reported previously 2 . Specifically, 94\% of the 83 models examined in this review used the Brazilian Institute of Geography and Statistics (IBGE)-defined categories (i.e., branca, preta, parda, indígena, amarela), or similar proxies. Of those studies that specifically focused on racial patterns in health, $89 \%$ of the models used these categories.

Regarding the modeling approach to race in those 78 models that used IBGE-derived categories, $52 \%$ measured all five race categories - but did not model the amarela and indigena categories in any way (i.e., either as distinct categories or combined with other categories). An additional 22\% of the models did not clearly lay out which categories were measured and modeled. When assessing how the 
categories were combined for modeling, $61 \%$ of models combined any non-branca categories, with a few more models combining branca with amarela categories.

Finally, regarding the general modeling strategy used, $23 \%$ of models were estimated with hierarchical regression approaches; notably, these approaches were used only in studies where race was not the explicit focus. Nevertheless, this resulted in many race coefficients reported without any confounder adjustment because they were dropped from covariate-adjusted models. Furthermore, a substantial number of articles were excluded initially from evaluation because of hierarchical regression approaches were used and unadjusted models were not reported so that it was not possible to examine even unadjusted race coefficients. Only $54 \%$ of the models estimated included adjustment for confounders without proximal mediators. Indeed, only $64 \%$ of the models in studies that focused specifically on race included adjustment for confounders without proximal mediators. (When examining racial patterns in health, race should be modeled with confounders - e.g., socioeconomic status - and covariates that improve precision - e.g., age, gender -, but not mediators - e.g., health behaviors).

\section{Infant health}

Twelve studies, published between 2001 and 2015, were evaluated. Generally, studies reported better infant outcomes for branca infants compared to non-branca infants which were attenuated, often (but not always) to statistical nonsignificance after adjustment for socioeconomic status. Studies that used geographically ethnic ancestry (i.e., respondents reported whether their families included European, African, or native ancestry) to measure race reported better infant outcomes for European Brazilians compared to Brazilians of other geographically ethnic ancestry, which was attenuated to statistical nonsignificance after adjustment for socioeconomic status measures. Furthermore, one study that examined infant health over three time periods reported that inequalities have widened over time.

\section{Self-rated health}

Eleven studies, published between 2006 and 2014, were evaluated. The pattern of results diverged based on how the outcome measure was operationalized. In the dichotomization of the five-point self-rated health scale, if the term regular (the middle point most scales) was grouped with ruim and muito ruim, then results suggested that those in the branca group had better health compared to those in non-branca groups, even after adjustment for socioeconomic status. However, if regular was grouped with bom and muito bom, then results suggested no racial variation in self-rated health.

\section{Weight-related health}

Fifteen studies, published between 1997 and 2015, were evaluated. The pattern of results diverged by gender. Generally for men, there were no racial differences, particularly after adjustment for socioeconomic status. For women, studies using older data showed no racial differences, particularly after adjustment for socioeconomic status. However, studies using more recent data showed that nonbranca women were more overweight and obese compared to branca women.

\section{Discussion}

In this report, 38 empirical articles were examined for their approach to the measurement and modeling of race. Results show that most studies use IBGE-defined race categories or similar proxies. Scholars 2 have shown that most health studies model race without a clear conceptualization. As a social construct, the race variable is a proxy for the embodiment of racism in its structural (e.g., political power), cultural (e.g., stigmatization processes), and interpersonal (e.g., discriminatory treatment) forms 10 . The challenge then is to clarify the meaning of the racial categories in relation to health. For example, the parda category is likely heterogeneous capturing multiple competing aspects of racism. Many may identify as parda to reflect the national ethos of one Brazilian mixed race 11, which may vary by region or period. Relatedly, there have been increases in those who identify as preta, which likely 
reflect national conversations on race. Therefore, these categories may not consistently represent a clear, unified set of social exposures related to health over space and time. One approach to clarifying the aspects of racism related to health is to integrate the social science and humanities literatures that contain the information on the meanings of these categories over space and time, an approach that is increasing in use. Also, to better capture facets of the stigmatizing processes of cultural racism, some are examining skin tone as a complement or alternative to conventional measures of race.

Regarding the modeling of race, often, amarela and indígena groups were not modeled at all. Given the histories of disadvantage experienced by these groups, it is important to regularly document their health, as is done with other social groups in order to rectify any inequalities that reflect this social disadvantage. Many studies also combined racial categories, particularly preta and parda, when modeling health. Not only do these groups represent a hetergeneous mixture of diverging sociohistorical processes, as described in the example above, but they each also likely represent diverging social processes. For example, those who identify as preta may have darker skin tone on average, which may represent different exposures to stigmatizing processes compared those who identify as parda. Combining these two groups then makes it difficult to interpret the race coefficient.

Finally, regarding the modeling of covariates, only about half of the studies examined modeled race with potential confounders but without likely mediators, making it difficult to evaluate the race coefficients. Rather, more recent work includes potential mediators, but only after first modeling race with only its confounders. This approach, based on hypotheses of the factors that link racial group membership to health, can inform potential intervention points.

\section{Conclusion}

In summary, most studies employ measurement and modeling strategies with regard to race that make interpretation, and thus intervention on racial health inequalties, challenging. However, there is a growing literature based on explicit conceptualizations of race and its relation to health. As with previous reviews, it is recommended that future empirical work continue to outline explicit conceptual frameworks linking race to health. With a clear understanding of race as it is measured in specific studies, the literature can continue to better inform policy and other interventions to address health inequalities.

\section{References}

1. Chor D. Health inequalities in Brazil: race matters. Cad Saúde Pública 2013; 29:1272-5.

2. Kabad JF, Bastos JL, Santos RV. Raça, cor e etnia em estudos epidemiológicos sobre populações brasileiras: revisão sistemática na base PubMed. Physis (Rio J.) 2012; 22:895-918.

3. Laguardia J. O uso da variável "raça” na pesquisa em saúde. Physis (Rio J.) 2004; 14:197-234.
4. Laguardia J. Raça e epidemiologia: as estratégias para construção de diferenças biológicas. Ciênc Saúde Coletiva 2007; 12:253-61.

5. Travassos C, Williams DR. The concept and measurement of race and their relationship to public health: a review focused on Brazil and the United States. Cad Saúde Pública 2004; 20:660-78. 
6. Ribeiro TV, Ferreira LB. Description of color/race in Brazilian biomedical research. São Paulo Med J 2012; 130:115-8.

7. Wise PH, Pursley DM. Infant mortality as a social mirror. N Engl J Med 1992; 326:1558-60.

8. Idler EL, Benyamini Y. Self-rated health and mortality: a review of twenty-seven community studies. J Health Soc Behav 1997; 38:21-37.

\section{Resumo}

Recentes revisões têm discutido a conceitualização da raça em estudos sobre saúde no Brasil. Esta revisão descreve e discute temas específicos de medição e modelização de raça e como isso pode impactar a interpretação de resultados. Três bases de dados científicas foram usadas para buscar a literatura sobre raça e três resultados em saúde. A pesquisa encotnrou 38 estudos empíricos sobre os resultados do parto, auto-avaliação da saúde e peso. Os resultados sugerem que, embora existam padrões raciais na literatura em geral, os desafios conceituais e metodológicos podem ser abordados para esclarecer as formas em que a adesão ao grupo racial está ligada à saúde.

Grupos Étnicos; Determinantes Sociais da Saúde; Ciências Sociais
9. World Health Organization. Obesity: preventing and managing the global epidemic. Geneva: World Health Organization; 2000.

10. Jones JM. Prejudice and racism. 2nd Ed. New York: McGraw-Hill; 1997.

11. Bailey SR. Legacies of race: identities, attitudes, and politics in Brazil. Stanford: Stanford University Press; 2009.

\section{Resumen}

Recientes revisiones han discutido la conceptualización de la raza en estudios de la salud en el Brasil. Esta revisión documenta y discute temas específicos de medición y modelización con respecto a la raza y cómo esto puede impactar la interpretación de resultados. Tres bases de datos científicas fueron utilizadas para buscar la literatura sobre raza y tres resultados de salud. La búsqueda encontró 38 estudios empíricos sobre los resultados del nacimiento, la autoevaluación de la salud $y$ el peso. Los resultados sugieren que, si bien hay patrones raciales en la literatura general, desafíos conceptuales y metodológicos pueden ser abordados para aclarar las formas en que la pertenencia a grupos raciales está vinculada a la salud.

Grupos Étnicos; Determinantes Sociales de la Salud; Ciencias Sociales
Submitted on 17/May/2016

Final version on 09/Mar/2017

Approved on 21/Mar/2017 